\title{
Shark Cognition and a Human Mediated Driver of a Spate of Shark Attacks
}

\author{
Marie Levine ${ }^{1,2 *}$, Ralph S. Collier ${ }^{2,3}$, Erich Ritter ${ }^{2}$, Moustafa Fouda ${ }^{4}$, Vincent Canabal1,2 \\ ${ }^{1}$ Shark Research Institute, Princeton, USA \\ ${ }^{2}$ Global Shark Attack File, Princeton, USA \\ ${ }^{3}$ Shark Research Committee, Chatsworth, USA \\ ${ }^{4}$ Nature Conservation Sector, Egyptian Environmental Affairs Agency, Cairo, Egypt \\ Email: ${ }^{*}$ marie@sharks.org, sharkresearch@aol.com, erichritter@att.net, foudamos@hotmail.com, \\ vcanabal@comcast.com
}

Received 19 July 2014; revised 4 September 2014; accepted 22 September 2014

Copyright $@ 2014$ by authors and Scientific Research Publishing Inc.

This work is licensed under the Creative Commons Attribution International License (CC BY).

http://creativecommons.org/licenses/by/4.0/

(c) (i) Open Access

\section{Abstract}

Five unprovoked shark attacks are reported from Sharm-El-Sheikh, Egypt, between 30 November and 5 December 2010. Three of the five attacks are attributed to an oceanic whitetip shark, Carcharinus longimanus with a distinctive crescent-shaped notch in the upper lobe of the caudal fin. The shark was observed during the first attack on a snorkeler and photographed underwater during the second shark attack on a swimmer. In a video taken several months prior to the attacks, the same shark is hand-fed underwater by a divemaster with additional fish in a pack over his buttock. The shark can be seen swimming behind the divemaster while he removed additional fish from this pack. In Victims 1, 2 and 5, the shark removed an extensive amount of tissue from the victims' buttock. The three victims also lost a hand and/or a portion of their forearm, suggesting the injuries were inflicted by a shark conditioned to associating food with hand-feedings and the human form. The remaining two attacks, Cases 3 and 4, were attributable to the shortfin mako shark, Isurus oxyrinchus. This was determined from a unique dental pattern of the right side of the upper jaw due to a prior injury. This same "misalignment" dental pattern was observed in the injuries sustained by Victims 3 and 4. We conclude that the shortfin mako shark was responsible for the attacks on Victims 3 and 4, and the oceanic whitetip shark was the causal species of attacks on Victims 1, 2, and 5.

\section{Keywords}

Forensic Science, Red Sea, Sharks, Shark Attack, Shark Cognition

\footnotetext{
${ }^{*}$ Corresponding author.
}

How to cite this paper: Levine, M., Collier, R.S., Ritter, E., Fouda, M. and Canabal, V. (2014) Shark Cognition and a Human Mediated Driver of a Spate of Shark Attacks. Open Journal of Animal Sciences, 4, 263-269. 


\section{Introduction}

The number of shark/human interactions reported annually worldwide to the Global Shark Attack File (GSAF) is insignificant when ocean user group populations are considered, i.e. surfing, swimming, diving, kayaking, to note a few. Of the more than 5500 cases in the GSAF, 1466 occurred during the 21st Century from 2000 to 2013. Of the incidents reported during this 13-year period, 296 were eliminated. These include 117 questionable/post mortem cases, 11 air/sea disasters with multiple victims, 52 boat incidents, and 116 provoked attacks in which a shark was hooked, netted, shot, struck, grabbed by a human or in a captive enclosure. Of the remaining 1170 unprovoked cases, 126 were fatal, which is slightly more than $10 \%$ of the total unprovoked cases reported during that period.

Historically, unprovoked shark attacks are random events that are usually distributed sporadically over time and at varied locations. There are those exceptions where multiple shark attacks have occurred at the same location over varying periods of time, from just a few minutes, to days or even years [1]-[9]. Conditioning sharks to specific feeding locations and/or images was experimentally undertaken in a captive enclosure more than fifty years ago [10]-[13]. These experiments demonstrated the ability of sharks to learn and remember specifics that were desirable for obtaining food under the laboratory parameters that were utilized. Subsequently, cognitive ability in sharks has also been described in the more recent past [14] [15].

The 5 unprovoked shark attacks occurred over a six-day period, 30 November to 5 December 2010, along an $8 \mathrm{~km}$ stretch of coastline. Two pairs of attacks occurred within minutes and at two common sites, separated by only 22 hours. The 5th and final attack took place, to the south, on 5 December, one day after the beaches had been reopened. The short time span between the first 4 attacks strongly suggests that there was either a sudden transient attraction for the sharks, or that a constellation of environmental factors converged in the area that was a catalyst and conducive to the events.

We identified anomalies that may have triggered the attacks, reviewed the chronology of the attacks, victims' medical records, historical and current data on shark/human interactions at Sharm El-Sheik, interviewed witnesses, inspected attack locations, analyzed fisheries data, and hydrographic charts of the area. Based on the above, we determined 2 species of sharks were involved in the incidents: a shortfin mako shark, Isurus oxyrinchus, and an oceanic whitetip shark, Carcharhinus longimanus. We concluded that topography, demographics, and the feeding of small inshore reef-fish by tourists were contributing factors, but recent dumping of sheep carcasses off the resort areas and the hand-feeding of sharks were likely triggers for the events.

Case 1, Coral Bay, 30 November 2010: At mid-day, O.M., age 48, was snorkeling with her daughter $10 \mathrm{~m}$ from the floating jetty (floating dock) when she stopped and floated on her back. A shark grabbed her outstretched left arm, pulling her beneath the surface and severing her arm below the elbow. As she struggled to shore, the shark lacerated her right leg, and then bit her lower back and buttocks. She sustained a semilunar laceration of the lateral aspect of the right leg extending across the knee joint, an amputation/avulsion of the right forearm with the proximal two-thirds of soft tissue and ulna remaining posteriorly and less than one-third of the soft tissue remaining anteriorly, and a $40 \mathrm{~cm} \times 50 \mathrm{~cm}$ soft tissue avulsion extending from the iliac crests to the perineum with extensive loss of skin, adipose tissue, and muscle. There were also multiple lacerations and punctures to the left thigh.

Case 2, Coral Bay, 30 November 2010: Only minutes following the attack on O.M., and less than a hundred meters to the south, L.S., age 70, was attacked while swimming. She was $10-15 \mathrm{~m}$ from shore, and $10 \mathrm{~m}$ from a floating jetty in water 10 to $12 \mathrm{~m}$ deep, when a female oceanic whitetip shark severed her foot. The shark grabbed her right forearm, and she pummeled the shark with her left hand, sustaining lacerations to the palm and fingers. As she attempted to withdraw her right arm from the shark's mouth, the shark severed the arm below the elbow. She sustained an irregular amputation of the distal third of the left leg, irregular amputation at the mid forearm of the upper right extremity, and sustained multiple lacerations of the right palm and digits, with a large tissue avulsion of the right third digit with exposed tendon and bone.

Case 3, Ras Nasrani, 1 December 2010: At 10h55, V.K., age 46, was snorkeling with his wife and son at the edge of the reef at Ras Nasrani, when a shark, which he described as a large, dark-colored shark, began circling and coming close. The family rushed towards the shore and the shark followed. When he was just $4 \mathrm{~m}$ from shore, V.K. attempted to hit the shark's head with his dive mask and was bitten by the shark. He sustained multiple lacerations in a semicircular distribution of the right medial leg, extending approximately $10 \mathrm{~cm}$ above and below the knee. 
Case 4, Ras Nasrani, 1 December 2010: At 11h00, E.T., age 54, was snorkeling at Ras Nasrani. Lifeguards were calling people out of the water following the attack on V.K. (Case 3). E.T. was $40 \mathrm{~m}$ from shore, $20 \mathrm{~m}$ from the jetty in water 15 to $20 \mathrm{~m}$ deep when his left arm was grabbed by a shark. He pummeled the shark with his right hand. The shark released his left arm, and then grabbed his right hand and forearm. Lifeguards who pulled him from the water into their Zodiac reported seeing the dorsal fin of a shortfin mako shark, and a short time later an oceanic whitetip shark surfaced beside their craft. Most of the wounds sustained were tears to the musculature, which are typical of the smooth-edged teeth of a mako shark [16]. However, there were additional deep lacerations to the forearm that appeared to be made by the upper lateral serrated teeth similar to those of an oceanic whitetip shark. This victim sustained extensive tissue loss of the left upper extremity involving all soft tissue layers; exposed muscle, tendon and bone with apparent bony deformity. There were multiple horizontally-oriented linear lacerations of the dorsal forearm and wrist with exposed extensor tendons.

Case 5, Middle Garden, Sharm El-Sheikh, 5 December 2010: At 12h00, a day after authorities reopened the beaches, R.S., age 70, was snorkeling approximately $20 \mathrm{~m}$ from shore when she shouted that she was being attacked by a shark. Her injuries were not survivable [17] [18] and she was pronounced dead when taken from the water. She sustained amputation of the right upper extremity with loss of the distal two-thirds of the forearm. She also sustained complete amputation of the right lower leg, with complete tissue avulsion from the right thigh and the femur denuded of flesh along its entire length, the femur remaining articulated at the hip. In addition, she sustained complete tissue avulsion overlying the posterior pelvis.

\section{Methods}

The chronology of the attacks was established, the medical records obtained from Sharm El-Sheikh Hospital were reviewed, and historical data on shark/human interactions in the Red Sea was obtained from the Global Shark Attack File in Princeton, New Jersey. The Egyptian Environmental Affairs Agency provided sea surface temperatures, lunar cycle, photographs of the captured mako shark dissection and videos of shark feeds. CNN provided footage taken by a tourist of one of the attacks, and the Hurghada Environmental Protection and Conservation Association provided additional data regarding diving practices in the Red Sea. The Chamber of Diving and Water Sports (Egypt) arranged interviews with witnesses and assisted in retrieving missing elements of the case histories. The Research Vessel "Red Sea Discovery" was utilized to photograph the coastline and obtain depth soundings of each incident location. Prior to arrival in Sharm El-Sheikh on 6 December, the surviving victims had flown home or been airlifted to Russia; however, we were able to locate one of the victims, and he, in turn contacted the others and assisted in arranging interviews.

\section{Discussion}

The five unprovoked shark attacks occurred along the $8 \mathrm{~km}$ beachfront north of Sharm el-Sheik, extending from Middle Gardens to Ras Nasrani (Figure 1). The inshore areas consist of sandy beaches that slope from $0.5 \mathrm{~m}$ to a shelving coral reef system at depths ranging from $11 \mathrm{~m}$ to $18.5 \mathrm{~m}$, after which the seafloor drops abruptly to $100 \mathrm{~m}$ and more. The seabed between Sharm El-Sheikh and the Strait of Tiran was not thoroughly charted until 2004 when a Boeing 737 - 300 crashed in the sea after takeoff from Sharm El-Sheikh airport. Data from the underwater recovery operations of the aircraft indicated the seafloor in the area varies in depth between 100 and $1420 \mathrm{~m}$ over relatively short distances [19]. Although the depth contours immediately adjacent to Middle Gardens were not available, just $260 \mathrm{~m}$ off the beach at Ras Nasrani the water depth is $100 \mathrm{~m}$. The presence of deep water close to shore and the canyons leading from the depths to shallow water along the beaches allows pelagic species, such as oceanic whitetip sharks and mako sharks, ready access to the inshore reef and the beach areas [20] [21].

Tooth impressions in tissues of victims 1, 2 and 5 were consistent with the dentition of an oceanic whitetip shark. This species of shark was observed prior to the attack on victim 1 and by three divers before and during the attack on Victim 2 and was photographed immediately afterwards (Figure 2). The shark, a $2.5 \mathrm{~m}$ TL female was identifiable by a distinctive, somewhat crescent-shaped, notch in the upper lobe of the caudal fin. The shark was subsequently observed and filmed by divers in Ras Za'atar, Ras Mohammed National Park, about $30 \mathrm{~km}$ to the southwest on 2 December. On 7 December, around midday, the shark was photographed again in Ras Mohammed and interacted with divers without incident. A search of the Global Shark Attack File to determine frequency of oceanic whitetip shark interactions with humans revealed a significant artifact. Of the 1170 unpro- 


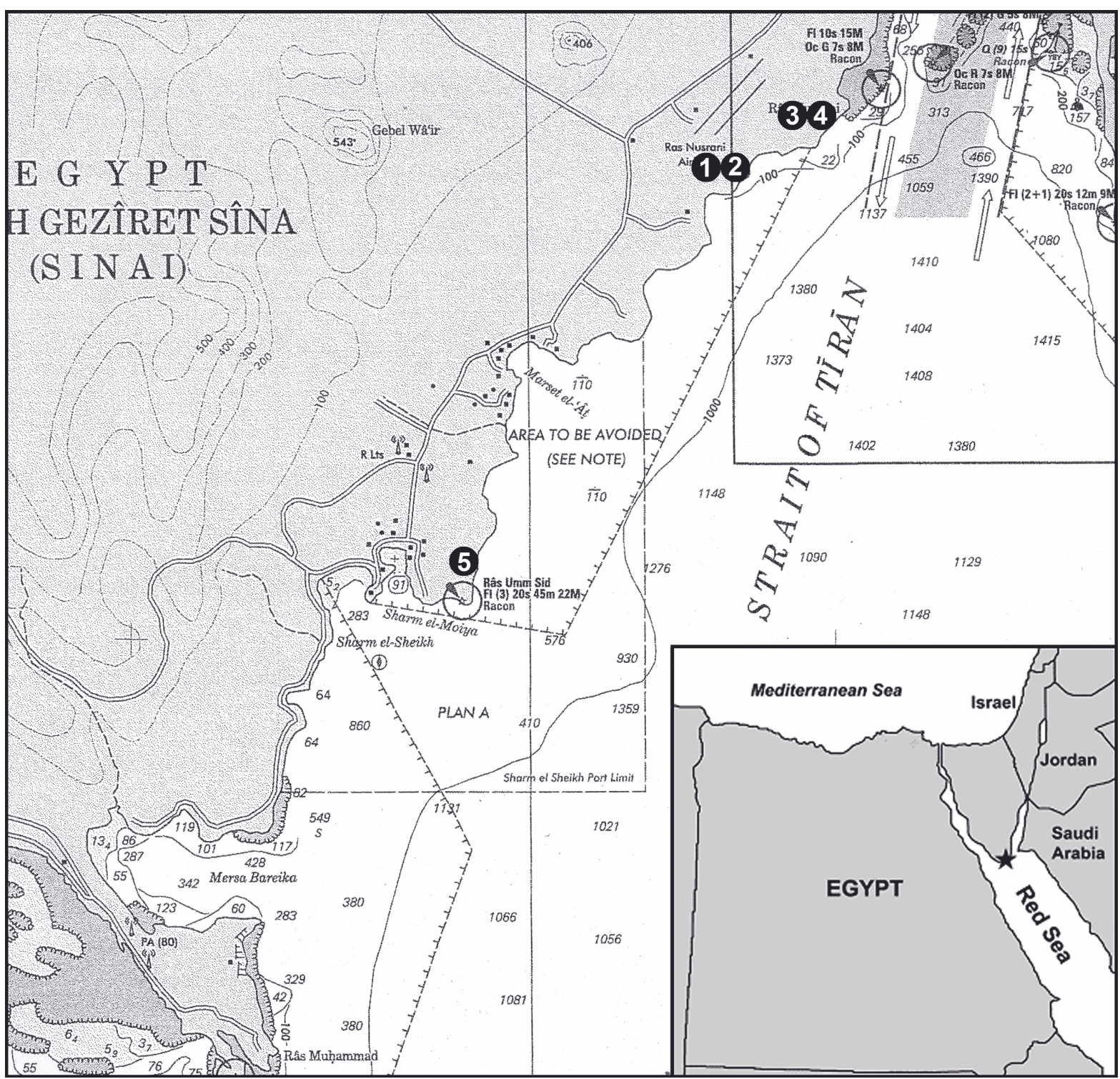

Figure 1. Locations of the 5 Sharm El-Sheikh cases.

voked cases reported to the GSAF from 2000 to 2013 identification of the causal species was obtained in 317 cases. The oceanic whitetip shark was positively identified in only 6 of these cases with all 6 occurring in the coastal waters of Egypt. It should be noted that over-fishing has reduced the number of natural prey available to sharks in the Red Sea, excluding those marine reef sanctuaries where plentiful fish populations exist and attract apex predators.

Victim 3: the shark tooth impressions of the victim's leg were consistent with those of a mako shark, and indeed, a witness on the jetty observed a shortfin mako shark in the immediate vicinity. The attack on Victim 4 occurred moments later and only a few meters away. If Victims 3 and 4 were attacked by the same shark, it suggests that the shark, repelled by its initial target, chose a secondary target and pursued it with more determination. Although this behavior has not been documented in mako sharks, similar behavior has previously been documented in white sharks, Carcharodon carcharias [22]. Following the removal of both victims from the water, and several minutes later, an oceanic whitetip shark was observed in the area.

On 3 December 2010, a shortfin mako shark was captured by local authorities of the National Park, South Sinai Sector. The tooth pattern on the medial thigh in Victim 3 matched the unusual upper jaw dentition of the captured shortfin mako shark. The shark had sustained an injury to the right side of the upper jaw, resulting in a 


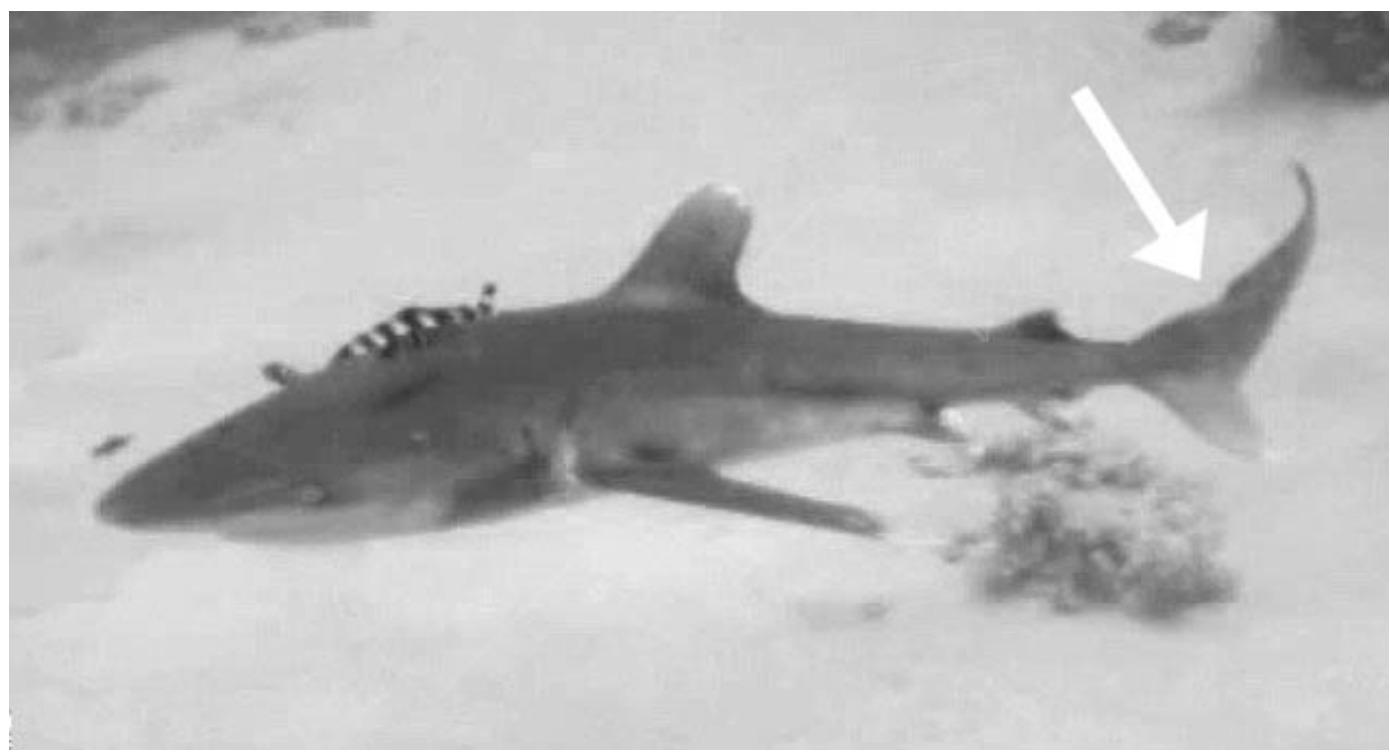

Figure 2. The oceanic whitetip shark determined to be the causal species responsible for the attacks on Victims 1, 2 and 5. Note the crescent-shaped notch in the upper lobe of the caudal fin. Photographs of a specific shark involved in an attack are extremely rare. While the quality of the photograph is not optimum, the photographer had just witnessed this shark attacking Victim 2.

misalignment of the anterior, intermediate, and first three lateral teeth (tooth terminology follows Applegate [23] and Martin [24]). Additionally, photographs of the posterior of the shark showed what appeared to be a number of bites to its posterior, which were comparable to those that would be inflicted by another shark. A photograph taken of the shark's internal organs, including the liver, during the necropsy showed it to be unusually small in size, suggesting it was malnourished. The poor physical condition of the shark suggests it may have been seeking atypical prey. According to records of the National Park, South Sinai Sector, mako sharks are rare in this region of the Red Sea; 2005 was the last time a shortfin mako shark was caught. However, there was a report of a shortfin mako having been observed farther south at Daedalus Reef about 4 weeks prior to this incident (Galal, pers.comm.).

Ambient water temperature is directly responsible for the metabolic rate of many shark species [25]. As water temperature increases, so does the metabolic rate of some shark species, which contributes to the sharks' necessity to feed more frequently to meet their energy demands. Records provided by the National Park, South Sinai sector indicated during the week that the attacks occurred, sea surface temperatures were $28^{\circ} \mathrm{C}-29^{\circ} \mathrm{C}$, much higher than normal $\left(19^{\circ} \mathrm{C}-23^{\circ} \mathrm{C}\right)$. The elevated sea temperatures created the need for sharks to consume more energy (food) more frequently. This "need to feed" would have caused sharks to venture into regions (close inshore) they might not normally utilize for hunting.

Multiple bites, such as those sustained by 4 of the 5 victims, usually involve a strong trigger such as predation, or feeding behavior. The sharks' actions suggest that they had been fed by dive operators who often brought sharks close for guests to photograph. Although shark feeding is prohibited by law, some dive operators continue this illegal practice. We were shown a video in which divers fed the sharks by hand and kept additional food in waist packs ("fanny packs") located above their buttocks. The wounds sustained by Victims 1, 2 and 5, in which their hands were severed and their buttocks removed, suggests the shark was seeking food from the areas of the body that it associated with prior feedings by divers [26]-[28]. The severed forearm sustained by Victim 2 could also be associated with the prior hand-feedings of the shark by divers. These cases strongly suggest the shark responsible had become habituated to being hand-fed in previous encounters with humans.

Of interest, too, is the time of day the events occurred, with all five subjects attacked around midday. This could represent a time of day sharks had been fed previously or, as noted by Baldridge in his 1975 global analysis, it could be the result of increased usage by resort guests during midday.

Hotel guests commonly feed the inshore reef-fish, despite signs along the beachfront cautioning them not to do so. There are numerous videos on public forums on the internet (youtube.com) of tourists feeding fish at 
Sharm El-Sheikh. There was an anecdotal report that hotel kitchen staff at one of the attack sites routinely provided guests with leftovers to feed the fish. Such practices may have also contributed to the two shark attacks at Sharm El-Sheikh which occurred on 4 April and 20 October 2010 (Global Shark Attack File). The canyons on the reef run from deep water to the shallows and serve as corridors along which both scent trails of food and sharks travel.

One of the most obvious factors is human population density. Five million people visit Sharm El-Sheikh annually (Hesham Galal, pers.comm.). As human usage of the sea increases in the area, so does the potential for negative interactions between sharks and humans.

However, the possible "tipping point" bringing the sharks close inshore may have been the recent dumping of sheep carcasses within $1.9 \mathrm{~km}$ of the shore by animal transport ships. After the carcasses were discarded from the ships, large and potentially dangerous sharks may have followed the dead animals as they were carried by currents and led the sharks close inshore near bathers, snorkelers, and divers. Most of the carcasses were removed from the water within 2 to 3 days, but some drifted ashore on beaches near the attack sites (Hesham Gabr, pers.comm.).

\section{Conclusion}

Any or all of the above factors may have contributed to the spate of attacks, although it is not possible to determine the parts played by each. First, there is a seawater corridor whose extreme depth enables pelagic sharks to come in close contact with a dense human population. This unique ocean topography allows pelagic species such shortfin mako and oceanic whitetip sharks, which normally range far from shore, to venture within meters of the local beaches. The feeding of fishes by swimmers, free divers, snorkelers, and scuba divers provides sensory stimuli to sharks utilizing the seawater corridor, attracting them to the shallow inshore waters. Although the marine life on the reef is a primary attraction for visitors to the area, it too draws sharks close inshore. While the tipping point may have been the sheep carcasses tossed overboard by passing vessels, the sudden onset of these attacks, together with the areas of the body bitten, strongly suggests that the oceanic whitetip shark was the causal species for the attacks on Victims 1, 2, and 5 with the shortfin mako shark responsible for the attacks on Victims 3 and 4. Motivation for these incidents appears to be the result of several artifacts with food the primary factor. The hand feeding by divers of the oceanic whitetip shark was probably contributory to its assaults. Conditioning of sharks using food as a reward has been previously tested experimentally [10]-[12]. The association, by sharks, of food (prey) and humans can have drastic and severe consequences as noted in these incidents. Although recommendations were made to euthanize the oceanic whitetip shark responsible for the attacks, the authorities have not taken action by this writing.

\section{Acknowledgements}

Special thanks are due to Syed Kalifa of the Egyptian Tourist Authority in New York and Hesham Gabr, Chairman of the Chamber of Diving and Water Sports (Egypt) who greatly facilitated our work in Sharm El-Sheikh. We also thank Hussein K. Salem who kindly provided an office for the team. We are particularly grateful to our colleagues, the members of the Senior Team of Forensic Investigators in Sharm El-Sheikh; including, Mohammed Salem of the Ministry of State for Environmental Affairs, and Hesham Gabr of the Chamber of Diving and Water Sports (Egypt). We are grateful for the assistance of Elke Bojanowski of the Hurghada Environmental Protection and Conservation Association (HEPCA) who provided background information on sharks and shark diving in the Red Sea. We also thank the government officials who participated in this investigation, including South Sinai Governor Mohamed Abdel Fadil Shosha, and General Amhmed Saleh Al Edkawy, Assistant Secretary General of The Governorate of South Sinai. We also wish to thank Viktor Koliy, Yuri Sobolev and Ilona Soboleva for their assistance in interviews with Russian victims and witnesses, and Oliver Ferrante who provided charts and bathymetric data of the area off Sharm El-Sheikh. Thanks are also due to Leonard J. V. Compagno for providing literature relevant to this study. Very special thanks to Dr. Jennifer V. Schmidt who reviewed this paper and provided suggestions for its improvement.

\section{References}

[1] Coppleson, V.M. (1933) Shark Attacks in Australian Waters. Medical Journal of Australia, 1, 449-467.

[2] Coppleson, V.M. (1950) A Review of Shark Attacks in Australian Waters since 1919. Medical Journal of Australia, 2, 
680-687.

[3] Coppleson, V.M. (1958) Shark Attack. Angus \& Robertson Ltd., London.

[4] Baldridge, H.D. (1975) Shark Attack. Berkley Medallion Books, New York.

[5] Miller, D.J. and Collier, R.S. (1981) Shark Attacks in California and Oregon, 1926-1979. California Fish \& Game, 67, 76-104.

[6] Collier, R.S. (1992) Recurring Attacks by White Sharks on Divers at Two Pacific Sites off Mexico and California. Environmental Biology of Fishes, 33, 319-325. http://dx.doi.org/10.1007/BF00005879

[7] Collier, R.S. (1993) Shark Attacks off the California Islands: Review and Update. In: Hochberg, F.G., Ed., 7rd California Islands Symposium: Recent Advances in Research on the California Islands, Santa Barbara Museum of Natural History, Santa Barbara, 453-462.

[8] Collier, R.S. (2003) Shark Attacks of the Twentieth Century: From the Pacific Coast of North America. Scientia Publishing, Chatsworth.

[9] Fernicola, R. (2001) Twelve Days of Terror: A Definitive Investigation of the 1916 New Jersey Shark Attacks. Lyons Press, Guilford.

[10] Clark, E. (1959) Instrumental Conditioning in Lemon Sharks. Science, 130, 217-218. http://dx.doi.org/10.1126/science.130.3369.217-a

[11] Clark, E. (1963) Maintenance of Sharks in Captivity with a Report on Their Instrumental Conditioning. In: Gilbert, P.W., Ed., Sharks and Survival, Heath \& Co., Boston, 115-149.

[12] Clark, E. (1978) Sharks That Ring Bells. In: Taylor, V., Taylor, R. and Goadby, P., Eds., Great Shark Stories, Harper \& Row Publishers, New York, 109-124.

[13] Aronson, L.R., Aronson, F.R. and Clark, E. (1996) Instrumental Conditioning and Light-Dark Discrimination in Young Nurse Sharks. Bulletin of Marine Science, 17, 249-256.

[14] Porcher, I.F. (2010) My Sunset Rendezvous. Strategic Book Group, Durham, Connecticut.

[15] Guttridge, T.L., van Dijk, S., Stamhis, E.J., Krause, J., Gruber, S.H. and Brown, C. (2013) Social Learning in Juvenile Lemon Sharks, Negaprion brevirostris. Animal Cognition, 16, 5-64. http://dx.doi.org/10.1007/s10071-012-0550-6

[16] Randall, J.E. and Levy, M.F. (1976) A Near-Fatal Shark Attack by a Mako in the Northern Red Sea. Israel Journal of Zoology, 25, 61-70.

[17] Byard, R.W., Gilbert, J.D. and Brown, K. (2000) Pathologic Features of Fatal Shark Attacks. The American Journal of Forensic Medicine and Pathology, 21, 225-229. http://dx.doi.org/10.1097/00000433-200009000-00008

[18] Byard, R.W., James, R.A. and Heath, K.J. (2006) Recovery of Human Remains after Shark Attack. The American Journal of Forensic Medicine and Pathology, 27, 256-259. http://dx.doi.org/10.1097/01.paf.0000221081.80866.5c

[19] Ferrante, O. and Vital, J. C. (2005) Underwater Recovery at 3300 Feet. ISASI Forum, 38, 14-17.

[20] Compagno, L.J.V. (1982) The Shark Fauna of the Red Sea. In: Abdel Latif, A.F., Bayoumi, A.R. and Thompson, M.F., Eds., Marine Science in the Red Sea, Proceedings of the International Scientific Conference on the Red Sea, Bulletin of the Institute of Oceanography and Fisheries (Egypt), Vol. 9, 381-406.

[21] Compagno, L.J.V. (1984) FAO Species Catalogue. Volume 4-Sharks of the World, Part 1-Hexanchiformes to Lamniformes and Part 2-Carcharhiniformes. United Nations Development Programme, Rome.

[22] Levine, M. (1996) Shark Attacks of Southern Africa In: Klimley, P.A. and Ainley, D., Eds., Great White Sharks: Biology of Carcharodon carcharias, Academic Press, San Diego, 217-222. http://dx.doi.org/10.1016/B978-012415031-7/50041-0

[23] Applegate, S.P. (1965) Tooth Terminology and Variation in Sharks with Special Reference to the Sand Tiger, Carcharias taurus Rafinesque. Los Angeles County Museum Contributions in Science, 86, 1-18.

[24] Martin, R.A., Hammerschlag, N., Collier, R.S. and Fallows, C. (2005) Predatory Behaviour of White Sharks (Carcharodon carcharias) at Seal Island, South Africa. Journal of the Marine Biological Association of the United Kingdom, 85, 1121-1135. http://dx.doi.org/10.1017/S002531540501218X

[25] Bushnell, P.G., Lutz, P.L. and Gruber, S.H. (1989) The Metabolic Rate of an Active, Tropical Elasmobranch, the Lemon Shark (Negaprion brevirostris). Experimental Biology, 48, 279-283.

[26] Ritter, E.K. and Levine, M. (2004) Use of Forensic Analysis to Better Understand Shark Behavior. Journal of Forensic Odonto-Stomatology, 22, 40-46.

[27] Ritter, E.K. and Levine, M. (2005) Bite Motivation of Sharks Reflected by the Wound Structure on Humans. The American Journal of Forensic Medicine and Pathology, 26, 136-40.

[28] Ritter, E.K., Lutz, K. and Levine, M. (2008) When Humans and Sharks Meet. In: Olsson, F.M., Ed., New Developments in the Psychology of Motivation, Nova Biomedical Books, New York, 45-52. 
Scientific Research Publishing (SCIRP) is one of the largest Open Access journal publishers. It is currently publishing more than 200 open access, online, peer-reviewed journals covering a wide range of academic disciplines. SCIRP serves the worldwide academic communities and contributes to the progress and application of science with its publication.

Other selected journals from SCIRP are listed as below. Submit your manuscript to us via either submit@scirp.org or Online Submission Portal.
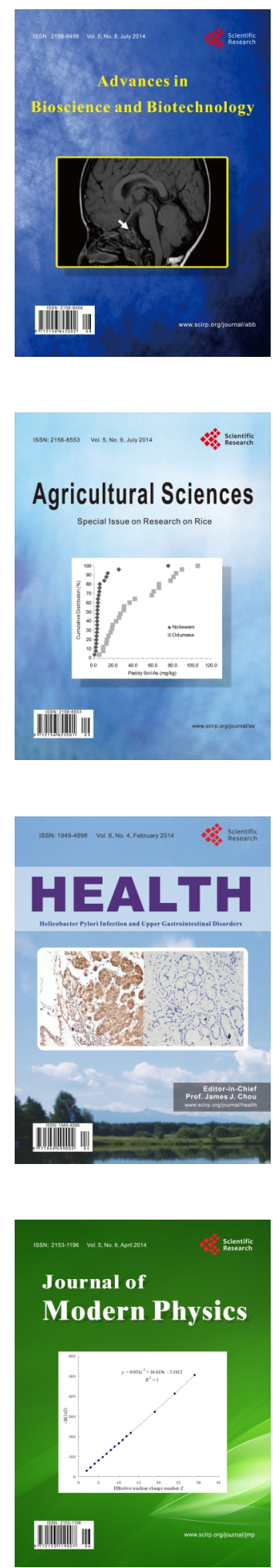
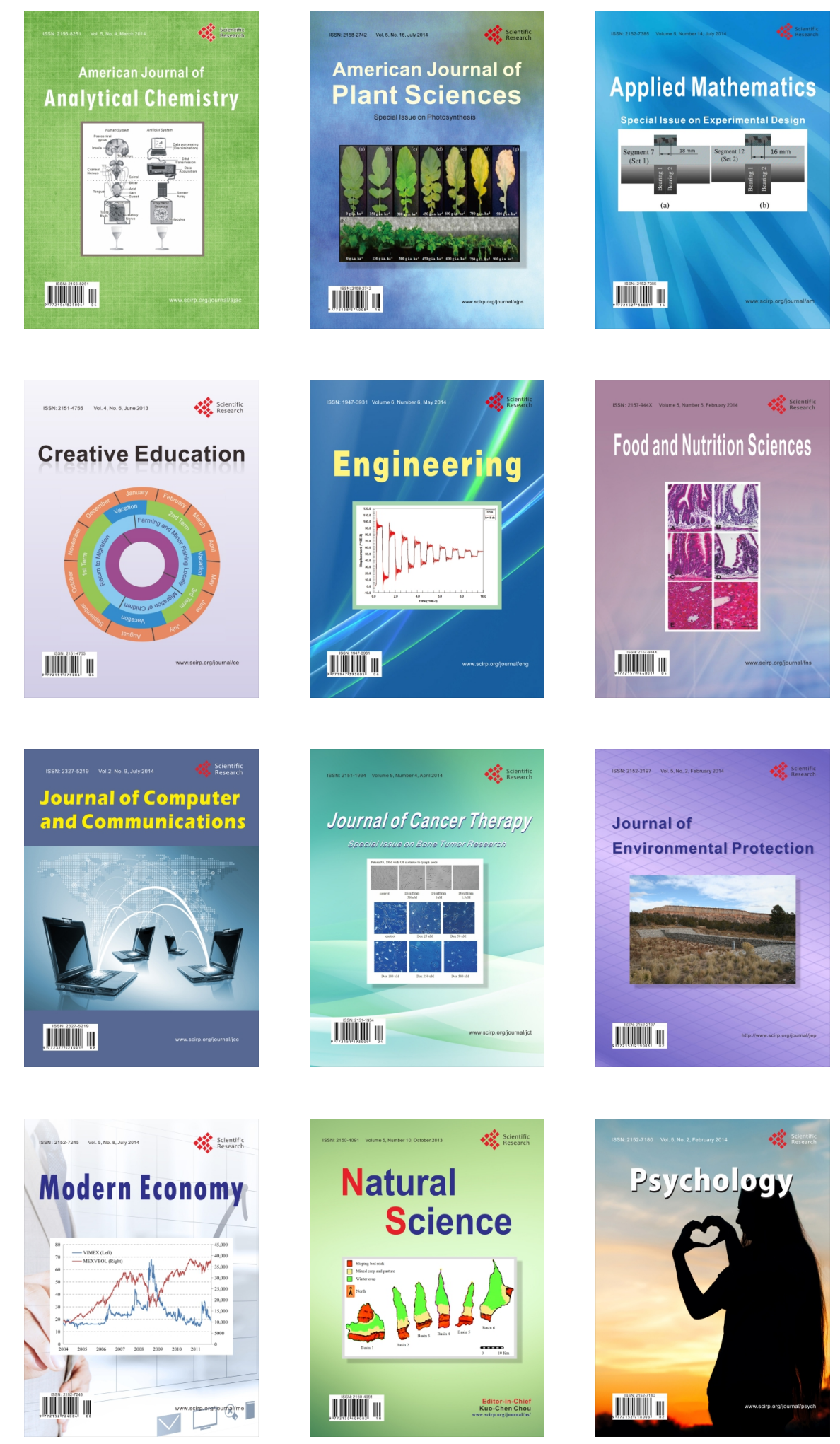